\title{
Review of environmental noise policies and economics in 2014-2016
}

\author{
DOI: $10.46981 /$ sfjhv2n1-004
}

Received in: November 1st, 2020

Accepted in: December 30th, 2020

\author{
Dietrich Schwela \\ $\mathrm{PhD}$, Senior Research Affiliate, SEI \\ University of York, Environment Department, Stockholm Environment Institute (SEI), York, UK \\ Address: Am Nachtigallental 28, 45149 Essen, Germany \\ E-mail: dietrich.schwela@york.ac.uk
}

\begin{abstract}
This review has highlighted the important developments relating to noise issues performed by international organizations and the activities in some developed and developing countries to improve environmental noise management.

The World Health Organization is in the process of finalizing the WHO Environmental Noise Guidelines for the European Region as an update of the WHO Community Noise Guidelines of 1999/2000.

The International Civil Aviation Organization, in Chapter 14, has lowered the current chapter 4 standards for subsonic jet aircraft and propeller driven aeroplanes.

In 2014-2016 the European Parliament and the Council and the European Commission have achieved significant progress in amending laws and regulations and creating new legislation. Efforts referred to regulating the EU type-approval of all new buses and trucks with regard to their sound level and the introduction of noise-related operating restrictions at airports, in accordance with ICAO's Balanced Approach. The EC amended the END and arranged for the evaluation of the END based on the criteria of relevance, coherence, effectiveness and impacts, efficiency, and EU added value. Two new regulations addressed the issues of technical specification for interoperability of high-speed trains related to sound emission levels and the implementation of provisions establishing noise-differentiated track access charges.

The European Environment Agency published the 'Noise in Europe' report describing the impacts of noise exposure in terms of cases of premature death, hospital admissions, cases of hypertension and annoyance. In addition, the European Environment Agency developed a good practice guide on quiet areas, refined the methodology for a quietness suitability index, and published its report on "Quiet areas in Europe".

In the United Kingdom, the Civil Aviation Authority reported new and updated evidence on attitudes to aviation noise around airports in England, and the Airports commission published recommendations for development in the aviation sector around London. The Department of Transport formulated a draft Airports National Policy Statement on expansion options for South East England airports.

Switzerland published its Environment Report 2015 and estimated the annual external costs of road traffic, railway and aircraft noise which are quite substantial.

Developing countries become increasingly aware that noise levels have gone up abnormally high and can cause acute and chronic health impacts on the human population. In consequence, Costa Rica has lowered the permissible sound pressure levels, and India, Iraq and Mexico have set new daytime and night-time noise standards. Tanzania has approved permissible sound pressure limits, which were prepared by the National Environment Management Council almost a decade ago. The Egyptian Environmental Affairs Agency developed a national plan to combat noise, which is currently
\end{abstract}


implemented on a collaborative effort of 11 ministries, a rare phenomenon in developing countries. Kenya is currently committed to develop a strategy for environmental noise management.

Keywords: Noise and health; Environmental noise management; Activities of international organizations; Activities in countries

\section{INTRODUCTION}

Urbanization and the associated growth in population mobility have resulted in the intensification of environmental noise, particularly in densely populated areas. International organizations and many developed and some developing countries are now taking action to enhance their institutional and technical capabilities to monitor and control noise exposure and implement preventive actions to reduce the risks that environmental noise poses to their citizens. This review provides an update of the report presented at ICBEN 2014 conference on international progress on noise mitigation policies and strategies, best practices and guidelines for environmental noise management [1].

\section{INTERNATIONAL BODIES}

\subsection{WORLD HEALTH ORGANIZATION}

Currently the European Office of the World Health Organization (WHO/Europe) is in the process of finalizing the WHO Environmental Noise Guidelines for the European Region as a regional update to the WHO Community Noise Guidelines [2]. The evidence of the health outcomes emerged since 1999 will be systematically reviewed: cardiovascular diseases, hearing impairment, cognitive impairment, mental health and wellbeing, sleep disturbance, annoyance, tinnitus and adverse birth outcomes.

The guidelines assess several environmental noise sources such as aircraft, rail, road, wind turbines and personal electronic devices. In addition, the guidelines will review the evidence on health benefits from noise mitigation and interventions to decrease noise levels.

\subsection{INTERNATIONAL CIVIL AVIATION ORGANIZATION}

The International Civil Aviation Organization (ICAO) continues its efforts to reduce the number of people affected by aircraft noise and ensure that the latest available noise reduction technology is incorporated into aircraft design. In 2014 the ICAO Council adopted the new Chapter 14 noise standard for subsonic jet aircraft and propeller-driven aeroplanes [1], [3]. It is applicable for new aeroplane types submitted for certification on or after 31 December 2017, and on or after 31 December 2020 for aircraft less than 55 tonnes in mass. 


\subsection{EUROPEAN UNION}

The European Parliament and the Council of the European Union (EU) adopted two regulations on noise issues, viz. No 540/2014 and 598/2014 [4], [5]. Regulation 540 establishes the administrative and technical requirements for the EU type-approval of all new buses and trucks with regard to their sound level, and of replacement silencing systems. It defines the test conditions of noise measurements for stationary vehicles and for vehicles in motion and sets limit values for measured sound levels emitted from new vehicles depending on the vehicle category. The regulation is to be implemented from July 1 , 2016 onwards. Sound levels of new vehicles have to be reduced amending those laid down in Directive 2007/46/EC in two further phases to be implemented by 1 July 2019 and 1 July 2027, respectively.

Regulation 598 lays down rules on the process to be followed for the introduction of noise-related operating restrictions at airports, so as to help decrease the noise exposure of people significantly affected by potentially harmful effects of aircraft noise, in accordance with the ICAO's Balanced Approach [3]. This regulation establishes a clear and transparent procedure to introduce operating restrictions so that decisions are evidence-based and offer optimal solutions for noise problems [5].

European Commission (EC) initiatives are mostly addressing issues related to the Environmental Noise Directive 2002/49/EC (END). In 2015 the EC revised Annex II of the END by adopting the common methods for calculating exposure to different noise levels. They comprise a set of formulas and coefficients to be used to calculate noise levels at the façade of buildings [6].

A revised Annex III of the END is currently being developed following the latest scientific review of the health effects of noise that is being performed by the WHO. This annex will describe the methods for calculating the burden of disease caused by exposure to specific noise levels. The methods will include dose-effect relations for a set of health endpoints such as cardiovascular disease, annoyance and sleep disturbance.

In 2013, the EC identified the END as one of the Directives "to be evaluated with a focus on regulatory fitness" in the context of the Regulatory Fitness and Performance initiative (REFIT) and the Better Regulation Programme [7], [8], [9]. This evaluation based on the criteria of relevance, coherence, effectiveness and impacts, efficiency, and EU added value and was performed in 2015 and 2016 [10]. The main results are [11]:

- The objectives of the END were found to remain relevant for EU policy-making.

- The END is coherent with other EU and national legislation; coherence within the legal text, however, could be improved.

- With regard to effectiveness and impacts, progress has been made towards a common approach to noise management and informing EU legislation for reduction of noise at the sources, however not used so far. Adoption of common assessment methodologies in the EU Member States has 
been slow, especially with respect to action plans.

- Where noise management action plans exist, the END was efficient with a favourable benefitcost ratio of almost 1.3.

- While the benefit-cost ratio indicates a substantial EU added value, increasing its effectiveness and impacts might enhance this figure.

The EC has passed two regulations in 2014 - technical specification for interoperability (TSI) of high-speed trains related to sound emission levels (Regulation No 1304/2014) [12] - and 2015 modalities of the charging for the cost of noise effects (Regulation No 2015/429) [13].

Regulation 1304/2014 amends Decision 2008/232/EC concerning a TSI for high-speed subsystems of the trans-European high-speed rail system by setting limits for sound level emissions for stationary noise, starting noise, pass-by noise, and driver's cab interior noise [10]. The regulation also specifies operation and maintenance rules, health and safety conditions, and procedures for conformity assessment and verification of the limit values.

The implementing regulation 2015/429 sets out the modalities to be followed by railway infrastructure managers for the application of provisions establishing noise-differentiated track access charges [13]. This amounts to giving a bonus (discount from the infrastructure access charges) to railway undertakings for lower noise 'retrofitted wagons', 'silent wagons', and 'silent trains' and a malus (surcharge to infrastructure access charges) for 'noisy wagons' and 'noisy trains'.

In the time period considered in this report two EC-LIFE projects were finalized:

- QUADMAP Quiet Areas Definition and Management in Action Plans [14].

- QUIET-TRACK Quiet Tracks for Sustainable Railway Infrastructures [15].

The main objective of QUADMAP project was to develop a harmonized methodology for selection, assessment (combining quantitative and qualitative parameters) and management (noise mitigation, increasing of usability of areas and user's satisfaction) of Quiet Urban Areas (QUAs). The final report is intended to facilitate urban planners to apply standard procedures for identification, delimitation and prioritization of QUAs.

QUIET-TRACK will focus on very effective track based rolling noise mitigating solutions for trams, regional trains, surface metro and trains in an urban environment with direct application possibility to conventional railway tracks outside the city. The Newsletter presents the results of the project with regard to

- Rail wheel interaction monitoring related to noise generation;

- Procedure for average wheel roughness determination;

- Rolling noise emission model for curving conditions; 
- Low frequency rolling noise emission model and software;

- Noise-related track maintenance \& management tool;

- Rolling noise reduction of Metro by track-based solutions.

\subsection{EUROPEAN ENVIRONMENT AGENCY}

The European Environment Agency (EEA) published a report titled "Noise in Europe 2014" to assess the scale of the noise challenge, the actions that are being taken and may need to be considered in the future [16]. Key messages include:

- Environmental noise causes in Europe each year

$\circ$ at least 10,000 cases of premature death;

○ 43,000 hospital admissions;

- more than 900,000 cases of hypertension.

- An estimated 125 million people are affected by environmental noise levels above $55 \mathrm{~dB} \mathrm{~L}_{\mathrm{den}}$, almost 20 million adults are annoyed and further eight million suffer sleep disturbance due to environmental noise exposure.

- Road traffic is the most dominant source of environmental noise.

- Deficiencies for a reliable assessment of exposure estimates include

○ incomplete reporting by European Union (EU) Member States;

○ significant inconsistencies due to lack of comparable and common assessment methods.

- Political objective of the EU is to decrease environmental noise pollution closer to the WHO guideline values by 2020 .

Also in 2014 the EEA published a good practice guide on quiet areas (GPG) [17]. A quiet area is defined in accordance with the END as an area that is undisturbed by environmental noise. Key messages of the good practice guide document include:

- The issue of good practice on quiet areas is far from being settled because:

○ Preferable selection criteria for quiet areas are still being explored;

- There are different types of quiet areas (agglomerations, open country, diverse functions, situations, natural sound pressure levels, access, visual and other qualities) requiring different selection criteria;

- It is too early to determine if the action plans required by the END to preserve quiet areas will turn out to be good practice.

- A methodology for a quietness suitability index (QSI) outside urban areas based on noise mapping results is proposed. 
- The economic benefits of quiet areas can be substantial as the social costs for environmental noise were estimated as amounting to:

- Euro 40 billion per year due to rail and road traffic noise across the EU;

- Approximately Euro 2 billion for Sweden due to reduced property value in noisy areas (80\%) and society costs of health impacts (20\%);

○ As much a GBP 2-3 billion per year in the UK.

- EU Member States are advised to:

- Give due consideration to existing areas of good acoustic quality;

- Seek inspiration for potential selection criteria for quiet areas from acoustic indicators, functionality, distance from noise sources, perceived acoustic quality, urban and open country range criteria, land use plans, and nature conservation plans;

- Determine a national QSI.

Building on the GPG the EEA published its report on "Quiet areas in Europe" in 2016 [18]. The report explores to what extent Europe's rural environment could be considered as undisturbed by environmental noise pollution. The objective was to apply existing knowledge on emissions from major transport and industrial noise sources outside urban agglomerations. The QSI introduced in the GPG has been combined with environmental noise data to assess and map potential quiet areas in Europe's open country as a whole and for individual Member States. The key messages of the report include:

- Approximately 18 per cent of Europe's rural areas can be considered quiet, but 33 per cent are potentially affected by noise exposure.

- Almost 27 per cent of Europe's protected areas in the network of Natura 2000 are havens of quiet, while 20 per cent of these areas are affected by noise pollution.

- The distribution of quiet areas in Europe is strongly related to population density and transport.

- Environmental noise pollution is greatly influenced by land use, elevation, distance from urban areas, and distance from coasts.

- Accessibility to potential quiet areas varies across Europe dependent on settlement patterns.

- Much has to be done to reduce noise pollution in protected areas.

\subsection{INTERNATIONAL INSTITUTE OF NOISE CONTROL ENGINEERING}

In April 2015 the International Institute of Noise Control Engineering (I-INCE) published a report of its Technical Study Group 9 on Metric for Environmental Noise Assessment and Control [19]. The aim of this report is to examine options for supplementing or replacing the day-evening-night sound level (DENL) by other metrics as a predictor of noise impacts, especially annoyance from transportation. 
The study reviews the basics of transportation noise regulatory policy, including the current approach of measuring noise, and identifies the limitations of DENL for predicting population annoyance. The study continues to address the rationales for equivalent-energy and threshold-based noise metrics or indicators, the rationale for noise metrics or indicators sensitive to temporal variability, the adaptation level hypothesis for prediction of noise annoyance induced by transportation noise exposure. This section also discusses the limitations of A-weighted metrics as predictors of aircraft noise impacts and the advantages of amplitude- and frequency-dependent metrics acting as conventional analogous frequency filters such as Zwicker loudness, perceived noise levels, tone corrected perceived noise level, effective perceived noise level, and steady and time-variant loudness. A correlation analysis of the various noise metrics and indicators shows that nearly all of them are highly correlated with DENL, therefore being unlikely to substantially improve the DENL metric for typical airport operations. The only supplemental metric identified in the study as characterizing community response to transportation noise is the "Community Tolerance Level" (CTL) that implicitly includes the impacts of low frequency noise annoyance and noise-induced rattles. CTL is a noise level determined by least squares fit in an exponential relation between the per cent of highly annoyed subjects exposed at a location within the community and the day-night average sound level in $\mathrm{dB}$.

\section{ACTIVITIES IN COUNTRIES}

\subsection{COSTA RICA}

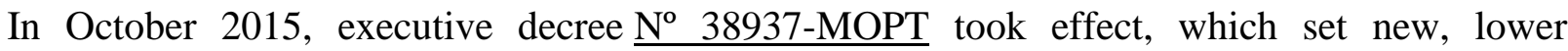
permissible limits on the sound pressure levels of vehicles, updating the existing law No 7.331 of 1993 [20], [21]. The limits of the law of 1993 are compared with those of the 2015 decree in Table 1 . The decree also establishes specific protocols and procedures for testing sound pressure levels from vehicle exhaust systems, either on the road or at the mandatory technical vehicle inspection stations.

Table 1: Maximum sound pressure level at exhaust

\begin{tabular}{|l|l|l|l|}
\hline Vehicle category & Engine size & \multicolumn{2}{l|}{ Limit [dBA] } \\
\hline & & Decree of 2015 & Law 7.331 of 1993 \\
\hline Passenger vehicles & & 90 & 96 \\
\hline Light duty vehicles and microbuses & & 92 & $96-98$ \\
\hline Buses & & 94 & 100 \\
\hline Heavy duty vehicles & & 96 & 100 \\
\hline Motorcycles, motor bikes & $<250 \mathrm{cc}$ & 94 & 98 \\
\cline { 2 - 5 } & $>250 \mathrm{cc}$ & 96 & 98 \\
\hline
\end{tabular}




\subsection{EGYPT}

The Egyptian Environmental Affairs Agency (EEAA) of the Ministry of Environment developed a national plan to combat noise and reduce sources thereof [22]. This plan is currently implemented in a collaborative effort of all relevant ministries (Ministry of the Interior, Ministry of Tourism, Ministry of Planning and Local Development, Ministry of Health and Population, Ministry of Islamic Endowments, Ministry of Civil Aviation, Ministry of Education, Ministry of Trade and Industry, Ministry of Housing, Utilities and Urban Development, Department of Transport, Ministry of the Environment). The plan defines the responsibilities and obligations of each ministry. The ministries provide the technical support required and the data that will contribute to the implementation of the plan. These efforts include:

a. The expansion of the joint campaigns of EEAA to adjust for noise violations;

b. Development of maximum limits for the noise immission and emission;

c. Prohibition/limitation of vehicle horn use;

d. Environmental awareness campaigns including the media on the serious health impacts of noise;

e. Taking legal action with regards to sound emissions at commercial, industrial and public facilities including tourist facilities, wedding halls, hotels, and schools;

f. Environmental impact assessment of industrial, commercial facilities and new roads;

g. Enforcement of noise legislation in all provinces;

h. Inclusion of sound pressure level monitoring in air quality monitoring networks;

i. Restrict the use of loudspeakers in mosques and religious institutions;

j. Reduce aircraft noise exposure from landing and take-off by planning paths of aircraft and employ noise mapping based on sound pressure level measurements;

k. Introduce the environmental dimension within the curriculum at educational facilities;

1. Consider environmental planning as one of the key elements in urban planning;

m. Establish a code for energy efficiency of buildings so as to reduce air-conditioning and their noise emission;

n. Establishment of dedicated bicycle lanes to promote the use of bicycles as a means to reduce noise levels;

o. Apply local and international standards and specifications for levels of noise from the operation of railways and subways;

p. Implementation of a project to establish a network to monitor environmental noise and mapping of environmental noise and a database for noise levels;

q. Enhancement of capacities in noise management for the benefit of all ministries. 


\subsection{INDIA}

The Government of India is becoming increasingly aware that the growth of the vehicle fleet in urban areas increases noise levels due to honking and can cause acute and chronic health impacts on the human population. In July 2014, the Maharashtra Environment Department published standards for the use of horns and sirens. Sirens and multi-toned horns continue to be prohibited except for police cars, ambulances and fire brigades [23]. Their use is also prohibited in silence zones and at night-time except during a public emergency. The sound level of horns should not exceed the noise level of the vehicle engine by more than $10 \mathrm{~dB}(\mathrm{~A})$. In addition, honking is prohibited in areas declared as 'no honking areas/zones'.

On 10 October 2016, the Ministry of Environment, Forest and Climate Change has published a Draft Notification (for information of the public) to set sound pressure level standards for 'Airport Noise Zones' [24]. These standards supplement the noise standards of the Noise Pollution (Regulation and Control) Rules 2000 and are shown in Table 2:

Table 2: Sound pressure level limits in Airport Noise Zones

\begin{tabular}{|l|l|l|}
\hline \multirow{2}{*}{ Type of airports } & \multicolumn{2}{|l|}{ Limits in LAeq [dBA] } \\
\cline { 2 - 3 } & $\begin{array}{l}\text { Daytime } \\
\text { (6am to 10pm) }\end{array}$ & $\begin{array}{l}\text { Night-time } \\
\text { (10pm to 6am) }\end{array}$ \\
\hline Existing busy airports & 70 & 65 \\
\hline $\begin{array}{l}\text { Other existing airports \& } \\
\text { upcoming/new airports }\end{array}$ & 65 & 60 \\
\hline
\end{tabular}

The limits shall have a tolerance limit of $10 \mathrm{~dB}(\mathrm{~A})$ and exclude aircraft landing and take-off noise. The standards within the boundary of an airport are identical with those set for an industrial area (daytime $75 \mathrm{dbA}$, night-time $70 \mathrm{dBA})$.

\subsection{IRAQ}

On 7 December 2015 Iraq promulgated its Law No. 41 on Noise Protection and Control [25]. The law amends previous legislation, regulates methodological issues in noise control, sets limits for exposure times to continuous noise between 80 and $115 \mathrm{dBA}$, and determines daytime and nighttime standards for outdoor noise exposure as shown in Table 3. 
Table 3: Iraq standards on environmental noise

\begin{tabular}{|l|l|l|}
\hline Zone & \multicolumn{2}{|l|}{ Noise level [dBA] } \\
\hline & $\begin{array}{l}\text { Daytime } \\
\mathbf{( 7 . 0 0 - 1 9 . 0 0 )}\end{array}$ & $\begin{array}{l}\text { Night-time } \\
\mathbf{( 1 9 . 0 0 -} \\
\mathbf{7 . 0 0})\end{array}$ \\
\hline Silence (hospitals, retirement homes, etc.) & 50 & 40 \\
\hline Urban residential & 60 & 50 \\
\hline Suburban residential & 55 & 45 \\
\hline Rural areas & 55 & 40 \\
\hline Educational (schools, universities) & 55 & 45 \\
\hline Industrial areas & 70 & 60 \\
\hline Commercial, administrative & 65 & 60 \\
\hline Air port, railway stations, harbours & 70 & 60 \\
\hline Parks & 60 & 50 \\
\hline Mixed residential commercial & 60 & 50 \\
\hline Mixed residential industrial & 60 & 40 \\
\hline
\end{tabular}

\subsection{KENYA}

The Ministry of Environment, Water and Natural Resources refined 'The National Environment Policy' in October 2014 [26]. With respect to noise the Government is committed to:

a. Develop a national strategy on noise pollution

b. Strengthen capacity and infrastructure to monitor, enforce and regulate noise pollution.

This policy seems to be a step forward to enforce the existing control regulations of 2009 [27].

\subsection{MEXICO}

Mexico's official noise norm NOM-081-SEMARNAT-1994 was first published in 1995 and set maximal permissible sound pressure levels for stationary sources. For daytime (6am to $10 \mathrm{pm}$ ) the limit at a receptor site was set to $68 \mathrm{dBA}$ and for night-time (10pm to 6am) to $65 \mathrm{dBA}$. In November 2013, Mexico modified the technical details attached to its noise norm, and issued new maximum permitted noise levels in a variety of different settings, see Table 4 [28].

Table 4: Maximum permissible sound pressure levels

\begin{tabular}{|l|l|l|}
\hline Area & Time duration & Limit [dBA] \\
\hline Residential (outside) & Daytime & 55 \\
\hline & Night-time & 50 \\
\hline Industrial \& commercial & Daytime & 68 \\
\hline & Night-time & 65 \\
\hline School (outside) & During breaks & 55 \\
\hline $\begin{array}{l}\text { Ceremonies, festival \& } \\
\text { entertainment events }\end{array}$ & 4 hours & 100 \\
\hline
\end{tabular}

Daytime: 6am to $10 \mathrm{pm}$. Night-time: $10 \mathrm{pm}$ to $6 \mathrm{am}$. 
The limits apply to "fixed sources" of noise rather than mobile sources such as vehicles, construction machines, leaf blowers, diesel generators, etc.

\subsection{SWITZERLAND}

According to the Environment report 2015 every fifth inhabitant (i.e. 1.6 million people) is affected by excessive road traffic noise during daytime and around 70,000 people are exposed to excessive railway noise [29]. During night-time road traffic noise affects 1.4 million people and 140,000 people are exposed to railway noise. Approximately 67,000 people are affected by aircraft noise during the day, and 95,000 at night-time. These impacts incurred external costs of road traffic, railway and aircraft noise of approximately CHF 1.8 billion in 2010, see figure 1.

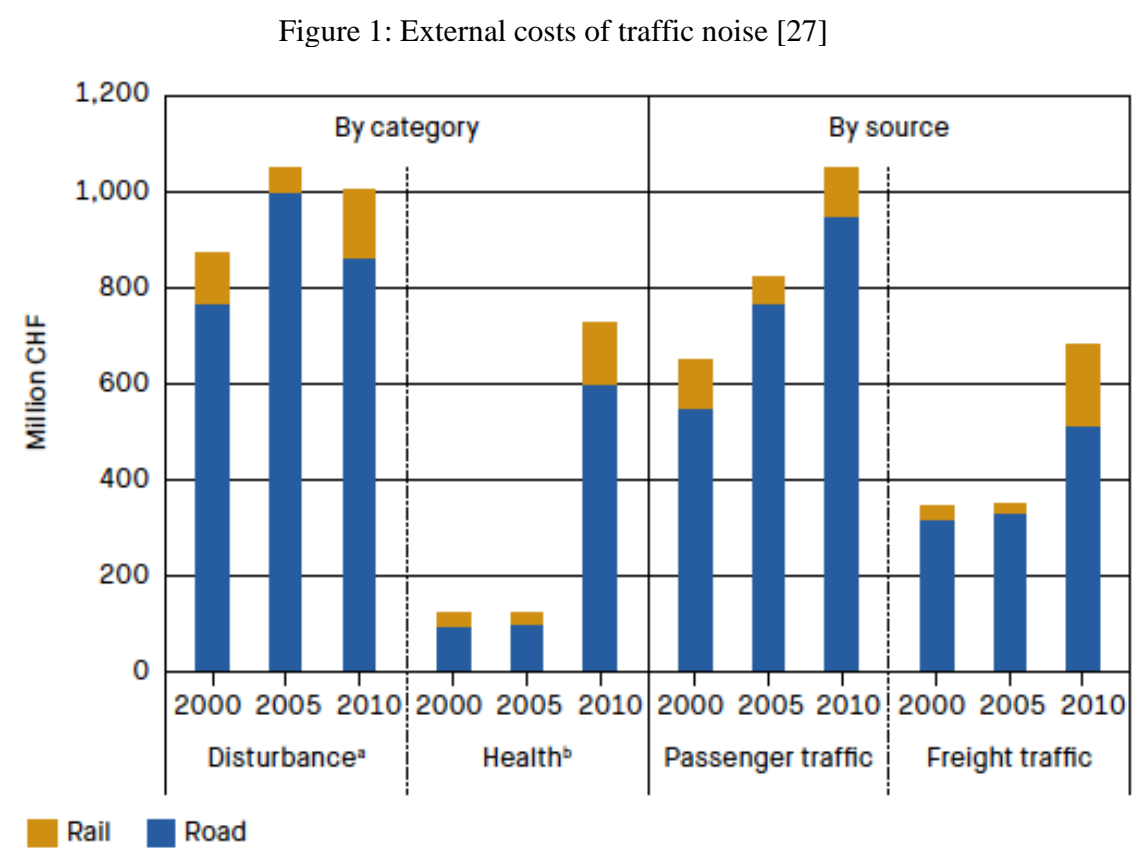

a: based on depreciation in property values.

b: based on treatment costs and production losses.

Figure 1 clearly indicates the increasing costs of passenger and freight traffic. These costs are not borne by the noise polluters but by public funds, indicating how little the polluter pays principle is used.

\subsection{TANZANIA}

In April 2015 the noise standards, which were prepared by the National Environment Management Council (NEMC) almost a decade ago, have been approved [30]. The standards are compiled in table 5. 
Table 5: Tanzanian maximum permissible sound pressure levels [31]

\begin{tabular}{|l|l|l|}
\hline \multirow{2}{*}{ Area } & Noise limit LAeq $[\mathbf{d B A}]$ \\
\cline { 2 - 3 } & $\begin{array}{l}\text { Daytime } \\
(\mathbf{6 a m} \text { to 10pm) }\end{array}$ & $\begin{array}{l}\text { Night-time } \\
(\mathbf{1 0 p m} \text { to 6 am) }\end{array}$ \\
\hline Sensitive* & 45 & 35 \\
\hline Residential & 50 & 35 \\
\hline Mixed residential/commercial & 55 & 45 \\
\hline Mixed residential/small scale industrial & 60 & 50 \\
\hline Industrial & 70 & 60 \\
\hline
\end{tabular}

* Hospital, Sanatorium, Convalescence home, retirement home, learning institutions, conference rooms, libraries, recreational sites.

Maximum permissible noise levels have also been set for continuous/intermittent noise from a factory/workshop and for impulsive noise. Making any loud, unnecessary noise is punishable by two years in prison, a $\$ 5,300$ USD fine or both. The regulation is meant to target primarily night-time noise from bars, venues, vehicles and houses of worship. The regulation states that loudspeakers cannot be used on any street for any reason at night.

The NEMC is currently engaged to enforce the regulation which is slow due to a shortage of staff and because those breaching the noise regulation have appealed the courts to challenge the fines [32].

\subsection{UNITED KINGDOM}

In 2017, the Civil Aviation Authority (CAA) reported work carried out under a Letter of Agreement placed by the Department for Environment, Food \& Rural Affairs (DEFRA) on the gathering of "new and updated evidence on attitudes to aviation noise around airports in England, and how they relate to the UK aircraft noise exposure indices" [33]. The study builds on earlier surveys on noise attitudes commissioned by DEFRA. Key results include

- $\mathrm{L}_{\text {Aeq,16h }}$ is still the most appropriate indicator for average summer day noise exposure to use to estimate the annoyance arising from aircraft noise.

- Evidence-based decisions should continue to use $\mathrm{L}_{\text {Aeq, } 16 \mathrm{~h}}$, but public information should use the better intelligible number of events of $65 \mathrm{~L}_{\mathrm{Amax}}$ indicator.

- The existing three-month summer average mode is still the best time period to use as opposed to single (easterly, westerly) mode.

- The mean annoyance score and the likelihood of being highly annoyed were found to increase with increasing noise exposure $\left(\mathrm{L}_{\mathrm{Aeq}, 16 \mathrm{~h}}\right)$.

- Non-acoustic factors such as noise sensitivity and expectations when moving to an area exposed to aircraft noise influence significantly reported annoyance.

The Airports Commission was set up in 2012 to find an effective and deliverable solution to the London airport capacity challenge. In 2013- 2014 the Commission has examined the implications of an 
expansion of airport capacity across a wide range of factors including noise, surface transport, employment, air quality, housing and local communities. In 2015 the Commission published a final report with recommendations for development in the aviation sector around London [34]. Key recommendations for measures of noise mitigation at Heathrow airport include:

- A ban on all scheduled night flights between 11:30pm and 6am.

- Agreement and enforcement of a clear 'noise envelope, which guarantees no overall increase of current noise levels.

- A homeowner and community compensation scheme for Heathrow Airport Ltd.

- A major shift in transport mode-share to reduce road traffic noise and congestion.

A number of documents reflect the background in the Airports Commission final report [35]:

- Noise: local addendum - Heathrow Airport extended northern runway offset route and single exposure level contours;

- Noise: aircraft noise effects on health;

- Noise: local assessment compendium of Ancon modelling results;

- Airports Commission compendium of results.

At least in part based on the Airports Commission's final report, the Department of Transport (DoT) has formulated a draft Airports National Policy Statement on expansion options for South East England airports (Heathrow, Gatwick) and initiated a public consultation on the statement in February 2017 [36]. Measures on noise mitigation are suggested to encourage the use of quieter aircraft and continuing the alternation of the airport's runways. The Government is also considering a legally binding ban on scheduled flights of a period of six and a half hours between $11 \mathrm{pm}$ and $7 \mathrm{am}$, subject to the International Civil Aviation Organization's balanced approach. Community compensation measures to homeowners are also envisaged. Once the public consultation closed in spring - summer 2017 the government will consider the responses received and a nominated Parliamentary Select Committee will scrutinise the Government's proposals 


\section{REFERENCES}

[1] Schwela, D., Finegold, L., Bristow, A.L., 2014. Environmental noise policy and economics: A review 2011-2013. ICBEN 2014, 1-5 June 2014, Nara, Japan. In: Basner et al., 2015. ICBEN review of research on the biological effects of noise 2011-2014. Noise \& Health 17(75): 57-82. https://www.ncbi.nlm.nih.gov/pmc/articles/PMC4918662/.

[2] Development of WHO environmental noise guidelines fort he European Region. From: http://www.euro.who.int/en/health-topics/environment-and-health/noise/activities/development-ofwho-environmental-noise-guidelines-for-the-european-region.

[3] On board a sustainable future. ICAO 2016 Environmental Report. International Civil Aviation Organization. Report from: www.icao.int/environmental-protection/Pages/env2016.aspx.

[4] Regulation (EU) No 540/2014 of the European Parliament and of the Council of 16 April 2014 on the sound level of motor vehicles and of replacement silencing systems, and amending Directive 2007/46/EC and repealing Directive 70/157/EEC. From: http://eur-lex.europa.eu/legalcontent/EN/ALL/?uri=CELEX\%3A32007L0046

[5] Regulation (EU) No 598/2014 of the European Parliament and of the Council of 16 April 2014 on the establishment of rules and procedures with regard to the introduction of noise-related operating restrictions at Union airports within a Balanced Approach and repealing Directive 2002/30/EC. From: https://ec.europa.eu/transport/modes/air/environment/aircraft_noise_en.

[6] European Commission - Environment. Noise. Policy development. From: http://ec.europa.eu/environment/noise/policy_dev_en.htm.

[7] Communication from the Commission to the European Parliament, the Council, the European Social and Economic Committee and the Committee of the Regions. Regulatory Fitness and Performance (REFIT): Results and Next Steps. COM(2013) 685 final. From: http://eurlex.europa.eu/legal-content/EN/TXT/?uri=CELEX:52013DC0685.

[8] Communication from the Commission to the European Parliament, the Council, the European Social and Economic Committee and the Committee of the Regions. Better regulation for better results - An EU agenda. $\operatorname{COM(2015)~} 215$ final, 19.05.2015. From: https://ec.europa.eu/info/law/law-makingprocess/better-regulation-why-and-how en\#documents.

[9] Communication from the Commission to the European Parliament, the European Council and the Council. Better Regulation: Delivering better results for a stronger Union. COM(2016) 615 final, 14.09.2016. Better regulation: why and how? European Commission, policies, information and services. From: https://ec.europa.eu/info/law/law-making-process/better-regulation-why-and-how_en.

[10] REFIT evaluation of the Directive 2002/49/EC relating to the assessment and management of environmental noise. Commission staff working document $\operatorname{SWD}(2016) 454$ final. From: http://ec.europa.eu/environment/noise/evaluation_en.htm.

[11] Evaluation of Directive 2002/49/EC Relating to the Assessment and Management of Environmental Noise. Final Report. European Commission, Centre for Strategy \& Evaluation Services, 2016. Report from: http://ec.europa.eu/environment/noise/evaluation_en.htm. 
[12] Commission regulation (EU) No 1304/2014 of 26 November 2014 on the technical specification for interoperability relating to the subsystem 'rolling stock - noise' amending Decision 2008/232/EC and repealing Decision 2011/229/EU. From: http://eur-lex.europa.eu/legalcontent/en/TXT/?uri=CELEX:32014R1304\&qid=1458073424915.

[13] Commission Implementing Regulation (EU) 2015/429 of 13 March 2015 setting out the modalities to be followed for the application of the charging for the cost of noise effects. From: http://eurlex.europa.eu/legal-content/EN/TXT/?uri=uriserv\%3AOJ.L_.2015.070.01.0036.01.ENG.

[14] Quiet Areas Definition and Management in Action Plans. Final report covering the project activities from 01/09/2011 to 31/03/2015. Reporting date June 2015. LIFE Project Number LIFE10 ENV/IT/407. From: http://www.quadmap.eu/.

[15] QUIET-TRACK Quiet Tracks for Sustainable Railway Infrastructures. Newsletter May 2016. From: http://www.quiet-track.eu/final-quiet-track-newsletter-may-2016/.

[16] European Environment Agency. Noise in Europe 2014. EEA report No 10/2014. 18 December 2014. Report from: http://www.eea.europa.eu/publications/noise-in-europe-2014.

[17] European Environment Agency. Good practice guide on quiet areas. EEA Technical report No 4/2014. Report from http://www.eea.europa.eu/publications/good-practice-guide-on-quiet-areas.

[18] European Environment Agency. Quiet areas in Europe - The environment unaffected by noise pollution. EEA Report No 14/2016. Report from: http://www.eea.europa.eu/publications/quiet-areas-ineurope.

[19] International Institute of Noise Control Engineering. Supplemental metrics for day/night average sound level and day/evening/night average sound level. Final Report of the I-INCE Technical Study Group on Metrics for Environmental Noise Assessment and Control (TSG 9), 2015 April. Available from: http://i-ince.org/files/publications/iince151.pdf.

[20] Costa Rica approves stricter regulations for noise control from vehicles. The Tico Times News, April 27, 2015. From: http://www.ticotimes.net/2015/04/27/costa-rica-approves-stricter-regulationsfor-noise-control-from-vehicles.

[21] Reglamento para el control del ruido emitido por el escape de vehiculos automotores. Decreto No 38937-MOPT. From: faolex.fao.org/docs/pdf/cos145386.pdf.

[22] The National Plan to Combat Noise and Reduce its Sources. Ministry of Environment, Egyptian Environmental Affairs Agency, 2016. From: http://www.eeaa.gov.eg/en-us/topics/air/noise.aspx.

[23] Environment department notification of 31st july 2014 standards for horns, sirens and/or multitoned horns for the vehicles plying in the state of maharashtra and their use. Maharashtra Pollution Control Board. From: http://mpcb.gov.in/envtdata/noisepollution.php.

[24] Government of India, Ministry of Environment, Forest and Climate Change Notification. From: http://www.moef.nic.in/content/inviting-comments-draft-notification-airport-noise-standards. 
[25] Law No. 41 of 2015 on Noise Protection and Control. International Labour Organization. From: http://www.ilo.org/dyn/natlex/natlex4.detail?p_lang=en\&p_isn=102971\&p_count=2\&p_classification $=14.01$.

[26] Republic of Kenya. Sessional paper no. 10 of 2014 on The National Environment Policy. Ministry of Environment, Water and Natural Resources, October 2014. From www.environment.go.ke/.

[27] Legal Notice No. 61: The environmental management and coordination (noise and excessive vibration) (control) regulations, 2009. National Environment Management Authority. From: https://www.nema.go.ke/index.php?option=com_content\&view=article\&id=79\&Itemid=190.

[28] ACUERDO por el que se modifica el numeral 5.4 de la Norma Oficial Mexicana NOM-081SEMARNAT-1994, Que establece los límites máximos permisibles de emisión de ruido de las fuentes fijas y su método de medición. Diario Oficial de la Federación. From: http://www.dof.gob.mx/nota_detalle_popup.php?codigo=5324105.

Environmental report 2015, II. State of the environment, 16. Noise. Report from: https://www.bafu.admin.ch/bafu/en/home/documentation/reports/environmental-report-2015.html.

[30]

Noise pollution standards finally in effect. Dar Post, April 17, 2015. From: http://www.darpost.com/2015/04/noise-pollution-standards-finally-in-effect/.

[31] National environmental standards compendium. Tanzania Bureau of Standards. From: https://www.google.de/url?sa=t\&rct=j\&q=\&esrc=s\&source=web\&cd=3\&ved=0ahUKEwjh9_vfi5rSA hXEuRQKHadBa8QFggrMAI\&url=http\%3A\%2F\%2Fwww.tzdpg.or.tz\%2Ffileadmin $\% 2 \mathrm{~F}$ migrated\%2Fcontent_up loads\%2FNational_Environmental_Standards_Compendium.pdf\&usg=AFQjCNHP7SViAYNtXX8j2 $\underline{\text { R3R3YBucmbStQ\&sig2=MjxF211BBfpF5UXbW_PfzQ. }}$

Tanzania: NEMC set to act on noise pollution. The Citizen, 2 March 2016. From; http://allafrica.com/stories/201603021395.html.

Survey of noise attitudes 2014: Aircraft. Policy Programmes Team, Civil Aviation Authority. Report from: publicapps.caa.co.uk/cap1506.

[34]

Airports Commission: Final report. July 2015. Report from: https://www.gov.uk/government/collections/airports-commission-final-report-and-supportingdocuments.

[35] Airports Commission final report: Noise. Report from: https://www.gov.uk/government/publications/airports-commission-final-report-noise. Consultation on Draft Airports National Policy Statement: new runway capacity and infrastructure at airports in the South East of England. Moving Britain ahead. February 2017. Department of Transport. Report from: https://www.gov.uk/search?q=Consultation+on+Draft+Airports+National+Policy+Statement $\% 3 \mathrm{~A}+$ ne $\underline{w+r u n w a y+c a p a c i t y+a n d+i n f r a s t r u c t u r e+a t+a i r p o r t s+i n+t h e+S o u t h+E a s t+o f+E n g l a n d}$. 